\title{
Belgian geographers at work
}

Results of a survey conducted in 2003

Les géographes belges et l'emploi. Résultats d'une enquête menée en 2003

\section{Isabelle Thomas, Ann Verhetsel and Frank Witlox}

\section{(2) OpenEdition}

Journals

Electronic version

URL: http://journals.openedition.org/belgeo/12329

DOI: $10.4000 /$ belgeo.12329

ISSN: 2294-9135

Publisher:

National Committee of Geography of Belgium, Société Royale Belge de Géographie

\section{Printed version}

Date of publication: 30 September 2005

Number of pages: $389-404$

ISSN: 1377-2368

\section{Electronic reference}

Isabelle Thomas, Ann Verhetsel and Frank Witlox, "Belgian geographers at work", Belgeo [Online], 3 | 2005, Online since 28 October 2013, connection on 05 February 2021. URL: http:// journals.openedition.org/belgeo/12329; DOl: https://doi.org/10.4000/belgeo.12329

This text was automatically generated on 5 February 2021.

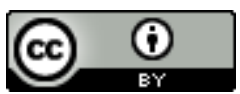

Belgeo est mis à disposition selon les termes de la licence Creative Commons Attribution 4.0 International. 


\section{Belgian geographers at work}

Results of a survey conducted in 2003

Les géographes belges et l'emploi. Résultats d'une enquête menée en 2003

Isabelle Thomas, Ann Verhetsel and Frank Witlox

We would like to thank Benoit Flahaut (UCL) and Veronique Van Acker (UGent) for the data centralisation and handling, and M. De Dapper (UGent), M. Erpicum (ULg), H. Nicolaï (ULB), I. Thomas (UCL), E. Van Hecke (K.U.Leuven), and Y. Verhasselt (VUB) for the local supervision of the enquiry.

\section{Introduction}

1 There is a long tradition among universities to know what their former students are professionally doing and what type of complementary studies and degrees their graduates have taken on. This is not different for geography. By knowing the occupational profile of the geography graduates one gets a better understanding of the role played by geographers, and what is more, in times of increased competition in trying to catch the attention of potential students to study geography, it is also a wellused marketing and PR instrument.

In Belgium, several survey studies are to be found in the last 20 years. First, there are the regular five years surveys of employment of geography graduates of the Université Catholique de Louvain (UCL) conducted by H. Beguin (1983, 1988, 1993, 1997). Second, there is the 1988-large-scale survey of the Katholieke Universiteit Leuven (K.U.Leuven) which gathers information on all of its geography graduates since 1937 (Depuydt, 1988). Third, there is the 1994-survey study of the Vereniging Leraars Aardrijkskunde (VLA) (Flemish Association of Geography Teachers) analysing the employment opportunities of young geographers that have graduated since 1980 from all three Flemish universities with a geography curriculum (Brussels, Ghent, and Leuven) (Saey and Vandewalle, 1996). Fourth, there is the survey of 1999, which was conducted under the auspices of the Belgian National Committee of Geography, and that documented on the occupational situation of nearly 1,500 geographers (Kesteloot et al., 2000). And finally, 
there is the most recent conducted survey by the Belgian National Committee of Geography of 2003, the results of which are presented in this paper.

Let us here remind that Belgian higher education differs from countries like France, Germany or the United Kingdom in a number of ways. In Belgium geography is embedded in the faculty of sciences, whereas in other countries human and physical geography are organised in other and/or separate faculties. Belgium has six universities which have a full geography curriculum in 2003: Katholieke Universiteit Leuven (K.U.Leuven), Université Catholique de Louvain (UCL), Université de Liège (ULg), Universiteit Gent (UGent), Université Libre de Bruxelles (ULB), and Vrije Universiteit Brussel (VUB). Up to the academic year 2003-2004 the standard period for obtaining a geography degree at the university in Belgium was four years, consisting of two years of "candidature" and two years of "licence", leading to a so-called licence degree. Following the Bologna agreement (2004-2005), all six universities are now engaged in a three year Bachelor programme, and a two year Master structure. The latter issue is however still under discussion in Flanders where a one year Master is being proposed by the Flemish government. Note also that in Namur (FNDP), 2 years of candidatures were formerly organised (incomplete curriculum). Because these students get their final degree in 2003 in one of the 6 other universities, Namur was not considered in our analysis. In the future Namur will give a Bachelor degree (3 years).

This paper is structured as follows. First, the survey and its response rate are briefly discussed. Second, an evaluation is made of the present employment situation of all geography graduates that filled in the questionnaire. Attention is paid to the type of employment (in education, outside education) and also to the first destinations (i.e. additional studies or first job) of geography graduates in 2003. Next, in Section 3, a brief overview of the complementary studies undertaken is presented. The paper concludes with an assessment of the changing context of the supply and demand for geography graduates by comparing the results over different graduation periods.

\section{The survey}

5 In October 2003, the Belgian National Committee of Geography decided to organise a survey of all Belgian geography alumni. The survey, which is mainly a follow-up of the 1999 survey (Kesteloot et al., 2000), focuses on the present employment and complementary studies of all geographers that graduated in one of the six universities mentioned above. Note that the universities of Gent (UGent) and Liège (ULg) also organise land surveying (landmeter/géomètre) within their geography curriculum, these responses are also taken into account.

Inspired by previous surveys, it was decided to use a brief (two pages) questionnaire which was sent to the last known address of 3,096 graduated geographers by regular mail. Each university was responsible for contacting its graduates. In total 1,722 (or 55.6\%) valid questionnaires were filled in and returned (see Table 1 and Figure 1). In Figure 1 each dot corresponds to one response located in the community of residence. The exact addresses are not known: the software generates at random the location of the dot within each commune. 
Table 1. Number of responses and response rate by university.

\begin{tabular}{lccc}
\hline University & $\begin{array}{c}\text { Questionnaires } \\
\text { sent }\end{array}$ & $\begin{array}{c}\text { Number of } \\
\text { responses }\end{array}$ & $\begin{array}{c}\text { Response } \\
\text { rate (\%) }\end{array}$ \\
\hline K.U.Leuven & 856 & 571 & 66,7 \\
UGent & 777 & 326 & 42,0 \\
UCL & 376 & 253 & 67,3 \\
ULB & 351 & 165 & 47,0 \\
ULg & 520 & 260 & 50,0 \\
VUB & 216 & 147 & 68,1 \\
\hline Total & 3.096 & 1.722 & 55,6
\end{tabular}

Figure 1. Geographical distribution of responses by place of residence.

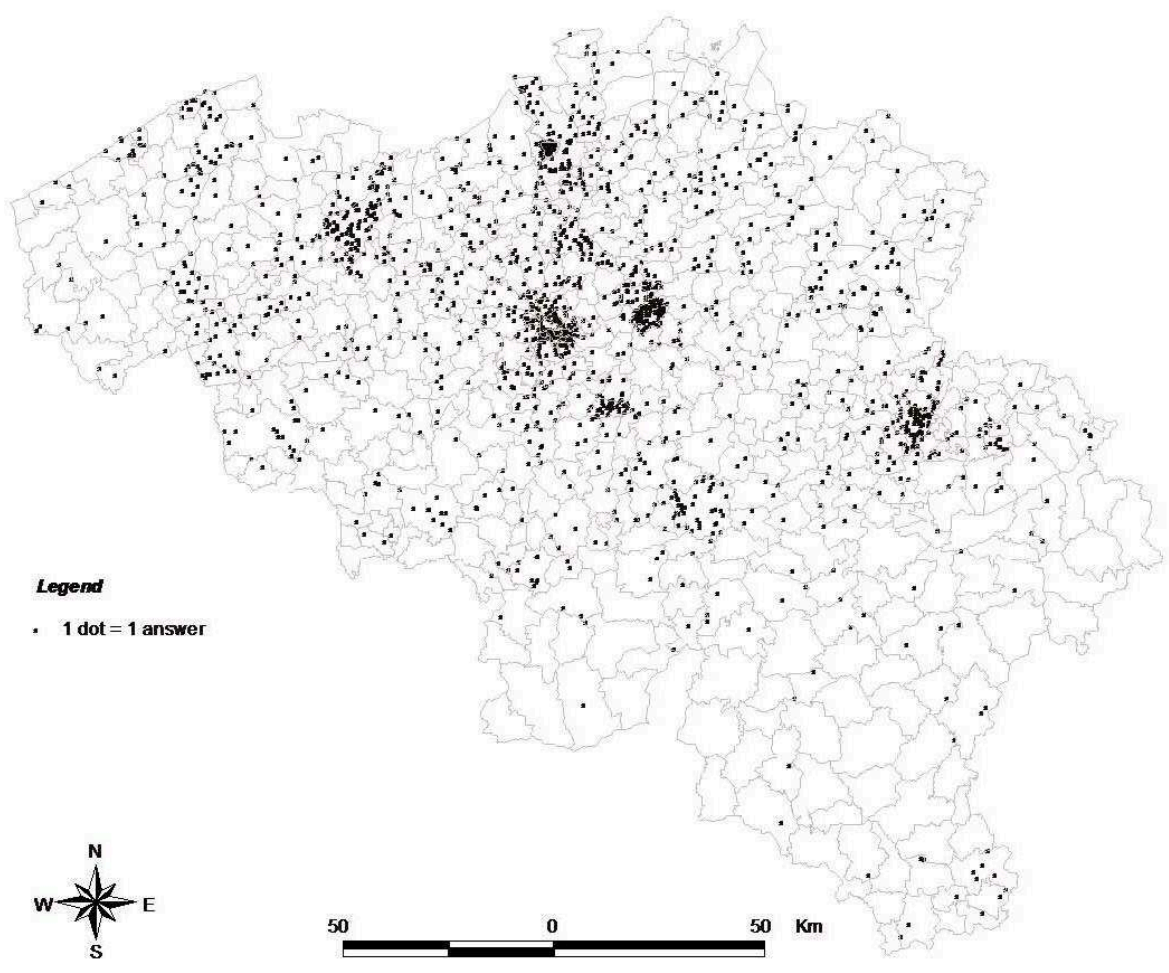

7 Compared to the survey of 1999 the response rate is somewhat lower (10\% lower). In absolute terms however the present survey generated 244 supplementary responses. According to Table 1, the VUB has the highest response rate, but at the same time the smallest number of students. The UCL and KULeuven have also a high response rate of two third, which is quite high nowadays given that people tend to refuse more and more to fill in written questionnaires. The UGent, ULB and ULg score below the average. Given that nothing is known about the non-response, corrections for different response rates are not possible. Note that a complete representativeness in terms of respondent's occupation, gender, university, or geographical specialisation is difficult to obtain. A certain bias is thus inevitable. Still, compared to previous snapshot surveys, it is fair to state that in view of the total response rate and the absolute number of graduates involved, the data may be considered as a reasonably reliable sample of geography graduates. 
8 Table 2 reports on the specialisation of the surveyed geography graduates in the last 2 years of their studies (licence). Human and economic geography dominate whatever the time period. This is followed by physical geography. The first land surveying graduates were only registered in the graduation period 1994-2003. The variations in the choice of geographical specialisation can be attributed to fashion effects, to contract opportunities, to the influence of leading research teams or professors, etc. Note also that the figures should be interpreted with some care because the computed percentages are sometimes calculated on small numbers. Let us note here that the distinction between physical and human geography fades with time: recent graduates have more problems to fill in this question that "older" ones.

Table 2. Geographical specialisation.

\begin{tabular}{lccccc}
\hline$\%$ & $<1974$ & $1974-1983$ & $1984-1993$ & $1994-2003$ & Total \\
\hline Physical & 36 & 33 & 28 & 33 & 32 \\
Human & 32 & 22 & 30 & 24 & 26 \\
Regional & 7 & 10 & 7 & 4 & 7 \\
Economic & 15 & 20 & 22 & 10 & 16 \\
Cartography/GIS & 4 & 2 & 6 & 7 & 5 \\
Surveying & 0 & 0 & 0 & 13 & 4 \\
Others & 2 & 4 & 3 & 7 & 6 \\
Not known & 3 & 100 & 100 & 100 & 100 \\
\hline Total & 100 & & & &
\end{tabular}

\section{Employment situation}

9 A substantial amount of questions in the survey relates to the global employment situation in September 2003. In what follows, we report on the global employment, then separately on the employment in education, and finally outside education.

\section{Present employment}

10 Table 3 gives the 2003 employment situation of all surveyed alumni per period of graduation. A threefold distinction is made: "working", "non-working", and "notknown". 
Table 3. Present employment.

\begin{tabular}{lcccc}
\hline$\%$ & $<1974$ & $1974-1983$ & $1984-1993$ & $1994-2003$ \\
\hline Working & 68 & 94 & 97 & 86 \\
Education & 43 & 53 & 36 & 17 \\
Outside education & 19 & 37 & 56 & 66 \\
Education + outside education & 6 & 4 & 4 & 3 \\
Non-working & 30 & 5 & 2 & 14 \\
Volunter work & 2 & 1 & 0 & 0 \\
Student & 0 & 1 & 0 & 7 \\
(Non-)registered job seeker & 0 & 0 & 1 & 5 \\
Non job seeker & 2 & 1 & 1 & 1 \\
Retired & 12 & 0 & 0 & 1 \\
Others (not traceable) & 14 & 2 & 0 & 0 \\
Not known & 2 & 1 & 1 & 100 \\
\hline Total & 100 & 100 & 100 & 1
\end{tabular}

11 The percentages of geographers having a job are very high, ranging from $94 \%$ for those that graduated between 1974-1983, 97\% for the 1984-1993 graduation period, and $86 \%$ for the period 1994-2003. The somewhat lower percentage for the latter period is not alarming, given that $7 \%$ of the respondents decided to continue with some supplementary studies. An interesting trend however is the fact that the market share between people having a job in education versus outside education is shifting rather dramatically. While more than half of the geography graduates of the 1974-1983 period were employed in education, this percentage drops to only $17 \%$ for the 1994-2003 period of graduation. In other words, in twenty years time, employment in education decreased by more than two thirds (Figure 2).

Figure 2. Percentage of active geographers, employed in education by year of graduation.

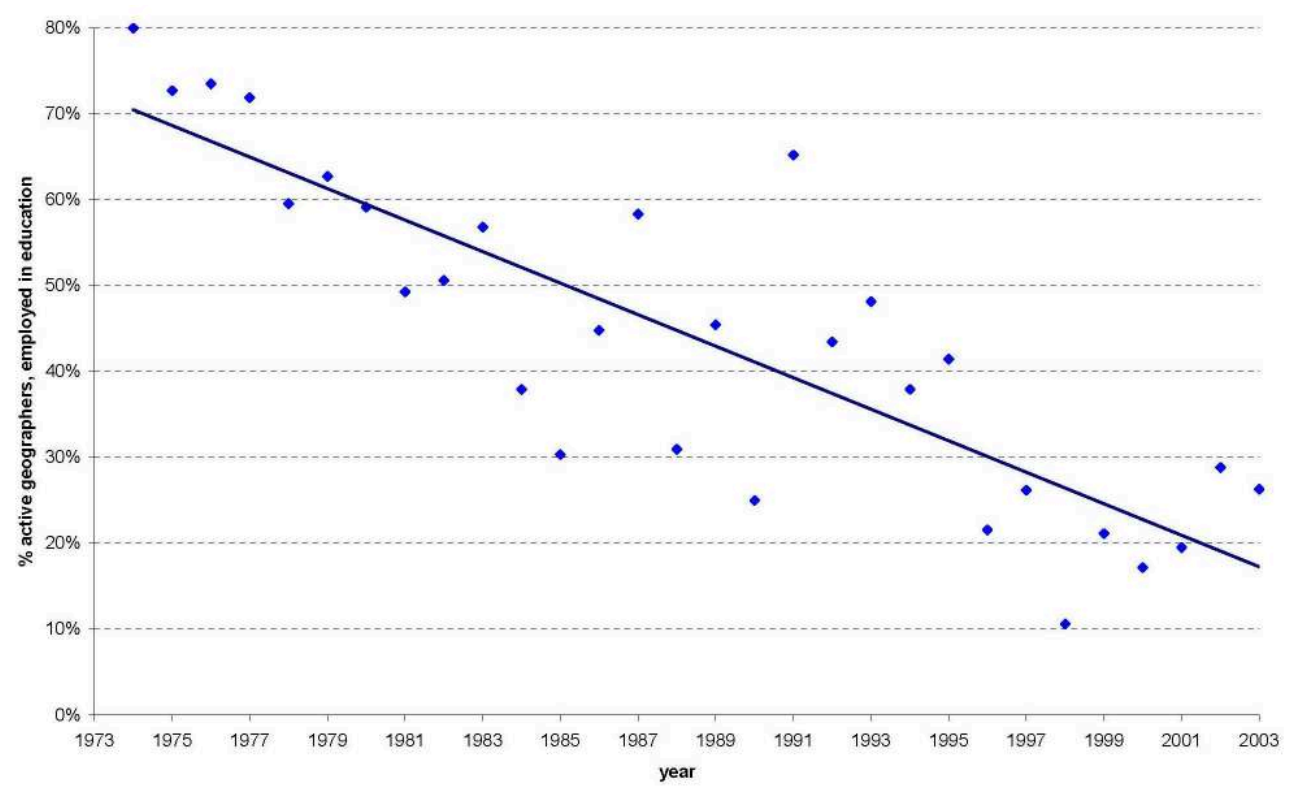

Looking at the non-working geographers (Table 3), it is found that the unemployment rate in general is very low. As an example, only $1 \%$ of all geographers that graduated between 1984 and 1993 is registered as job seeking. For the next period (1994-2003) this 
percentage rises to $4 \%$, which is still very low and was already mentioned formerly (Kesteloot et al., 2000, p. 246; Beguin, 1997). Let us here also add that the average period of unemployment is decreasing by year of graduation: 6 months (1974-1983), 5 months (1984-1993) to 3 months (1994-2003). To some extent, the low numbers of job seekers among geography graduates can be seen as a problem. For instance, the shortage of geographers in education has lead to the fact that non-geographers are being employed to teach geography.

13 Most of the surveyed active geographers have had more than one job (Table 4). This implies that some job changing has occurred. Note that Belgian teachers are employed and paid as civil servants. Hence, once being appointed, their employment position is normally completely secured. If the same group is asked whether they think that they are being employed because of their geography degree, a vast majority agrees (percentages ranging between 70 to $80 \%$ ) (Table 5).

Table 4. Answer to the question: "Is it your first job?".

\begin{tabular}{lcccc}
\hline$\%$ & $<1974$ & $1974-1983$ & $1984-1993$ & $1994-2003$ \\
\hline Yes & 42 & 34 & 23 & 47 \\
No & 51 & 60 & 69 & 53 \\
No answer & 7 & 6 & 8 & 1 \\
\hline Total & 100 & 100 & 100 & 100
\end{tabular}

Table 5. Answer to the question: "Why do you think you were/are employed?".

\begin{tabular}{lcccc}
\hline$\%$ & $<1974$ & $1974-1983$ & $1984-1993$ & $1994-2003$ \\
\hline Degree in geography & 76 & 62 & 56 & 78 \\
Other university degree & 3 & 5 & 7 & 6 \\
University skills & 13 & 12 & 13 & 7 \\
Other reason & 5 & 10 & 11 & 3 \\
Not known & 4 & 11 & 13 & 7 \\
\hline Total & 100 & 100 & 100 & 100
\end{tabular}

\section{Employment in education}

Although we know that the percentage of geography graduates being employed in education has decreased over the years, it still remains an important employment outlet. Therefore, it is worthwhile to take a closer look at the positions taken by geographers in the educational labour market.

Following the results of the survey, it seems that most geography graduates employed in education are working as a teacher in a secondary school (Table 6). Only $13 \%$ are employed in universities. Although it might be seen as rather self-evident: most courses taught by geographers are mainly related to geography (about 90\%), whatever the year of graduation (Table 7). Though one third of geography teachers seem to be troubled by the fact that they have to teach courses outside their main field of interest. We also record that about $10 \%$ of the "older" colleagues take management functions in schools; this results in an overrepresentation of geographers in school management. 
Geographers are known as entrepreneurial teachers, often organising fieldtrips, involved in integrated projects and using new media. This results in being asked and accepted more than others in school management positions.

Table 6. Type of education.

\begin{tabular}{lcccc}
\hline$\%$ & $<1974$ & $1974-1983$ & $1984-1993$ & $1994-2003$ \\
\hline Secondary school & 60 & 82 & 81 & 75 \\
College & 22 & 10 & 10 & 12 \\
University & 18 & 8 & 9 & 13 \\
\hline Total & 100 & 100 & 100 & 100
\end{tabular}

Table 7. Courses taught by geographers having a job in education.

\begin{tabular}{lcccc}
\hline$\%$ & $<1974$ & $1974-1983$ & $1984-1993$ & $1994-2003$ \\
\hline Only geography & 60 & 52 & 56 & 54 \\
Geography and others & 20 & 35 & 31 & 34 \\
Only others & 8 & 3 & 7 & 3 \\
Director & 7 & 4 & 3 & 1 \\
Other function & 5 & 5 & 1 & 4 \\
Not known & 0 & 2 & 1 & 4 \\
\hline Total & 100 & 100 & 100 & 100
\end{tabular}

16 In terms of gender, the questionnaire revealed that more women than men are employed in education. This is a trend that is noticeable since 1974. Table 8 refers to the type of work contract under which geographers are employed: we see clearly the difference for the last period of graduation. Indeed, whereas over $90 \%$ of the geographers that graduated before 1993 have tenured positions, this percentage becomes $39 \%$ for those that graduated in the last 10 years. Clearly, young teachers start on interim contracts and have to wait for teaching hours that become free. When the private sector offers at the same time interesting jobs and career opportunities, young geographers are attracted to these.

Table 8. Type of work contract in education.

\begin{tabular}{lcccc}
\hline$\%$ & $<1974$ & $1974-1983$ & $1984-1993$ & $1994-2003$ \\
\hline Non permanent & 5 & 4 & 11 & 55 \\
Permanent & 91 & 91 & 86 & 39 \\
Not mentioned & 5 & 5 & 3 & 5 \\
\hline Total & 100 & 100 & 100 & 100
\end{tabular}

\section{Employment outside education}

17 According to Table 3 there is a growing number of geography graduates that are employed outside education. The percentages vary from 37\% (1974-1983), 56\% 
(1984-1993), to 66\% (1994-2003). Table 9 shows in what type of activity these geography graduates are employed. The share of the private sector is loosing some ground over the public sector since 1984 .

Table 9. Employment outside education: private, public or NGO.

\begin{tabular}{lcccc}
\hline & $<1974$ & $1974-1983$ & $1984-1993$ & $1994-2003$ \\
\hline Private sector & 35 & 61 & 56 & 46 \\
Public sector & 63 & 37 & 40 & 49 \\
NGO & 3 & 3 & 3 & 4 \\
\hline Total & 100 & 100 & 100 & 100
\end{tabular}

During the period of economic crisis (starting in 1974-1983 and fading out from 1984), savings in education drove geography graduates to jobs outside education. The only growing economic sectors were in finance and the starting computer business. From the nineties on there were new opportunities in education, and as the absolute number of graduating geographers decreased, those who wanted to become a teacher had a fair chance to do so.

19 Table 10 and 11 give a more detailed idea of the employment outside education. Table 10 lists the different employment activities, regrouped in a number of categories. Table 11 gives an indication of the type of professional duty.

Table 10. Employment activities.

\begin{tabular}{|c|c|c|c|c|}
\hline$\%$ & $<1974$ & 1974-1983 & $1984-1993$ & $1994-2003$ \\
\hline \multicolumn{5}{|l|}{ Related to geography } \\
\hline Cartography, GIS, remote sensing & 5 & 5 & 9 & 17 \\
\hline Ecology, environmental management & 16 & 7 & 11 & 11 \\
\hline Geography, geology, meteorology & 0 & 2 & 3 & 5 \\
\hline Pesearch & 2 & 3 & 4 & 12 \\
\hline Surveying, topography & 0 & 1 & 1 & 5 \\
\hline Transport & 2 & 4 & 10 & 8 \\
\hline Spatial planning & 20 & 11 & 13 & 21 \\
\hline Tourism, recreation, catering & 4 & 6 & 6 & 2 \\
\hline \multicolumn{5}{|l|}{ Not related to geography } \\
\hline Administration & 5 & 3 & 2 & 0 \\
\hline Commercial, sales & 0 & 6 & 3 & 1 \\
\hline Economics, banking, insurance & 4 & 20 & 12 & 2 \\
\hline Computer sciences, telecommunication & 5 & 6 & 10 & 4 \\
\hline Non-profit, social sector & 9 & 1 & 1 & 2 \\
\hline Others (not traceable) & 23 & 23 & 12 & 8 \\
\hline Not known & 5 & 3 & 3 & 2 \\
\hline Total & 100 & 100 & 100 & 100 \\
\hline
\end{tabular}


Table 11. Type of professional duty.

\begin{tabular}{|c|c|c|c|c|}
\hline$\%$ & $<1974$ & $1974-1983$ & $1984-1993$ & $1994-2003$ \\
\hline Administration & 10 & 9 & 8 & 11 \\
\hline Civil servant & 10 & 6 & 6 & 3 \\
\hline (Commercial) delegate & 0 & 1 & 3 & 1 \\
\hline Consultant & 17 & 10 & 12 & 10 \\
\hline Employee & 5 & 13 & 18 & 16 \\
\hline Head of a department & 3 & 7 & 6 & 2 \\
\hline $\begin{array}{l}\text { Information scientist, } \\
\text { database engineer, } \\
\text { analyst programmer, GIS }\end{array}$ & 2 & 1 & 2 & 3 \\
\hline Inspector, police officer & 0 & 0 & 0 & 0 \\
\hline Lecturer, teacher & 9 & 2 & 3 & 2 \\
\hline $\begin{array}{l}\text { Manager, director, business } \\
\text { manager }\end{array}$ & 21 & 22 & 15 & 4 \\
\hline Political mandate & 2 & 1 & 1 & 1 \\
\hline Protession & 2 & 2 & 0 & 1 \\
\hline Scientific research, R\&D & 3 & 6 & 7 & 32 \\
\hline Senior officials, project manager & 7 & 11 & 14 & 9 \\
\hline Worker & 0 & 0 & 0 & 2 \\
\hline Not known & 9 & 7 & 6 & 3 \\
\hline Total & 100 & 100 & 700 & 100 \\
\hline
\end{tabular}

Table 10 shows that most geography graduates having a job outside education are working in a field closely related to geography. We can of course mention cases where graduates are working in a totally different area such as banks, insurance, telecommunications, etc. This trend is clearly illustrated when looking at the graduation periods 1974-1983 until 1994-2003. The employment percentages increase from $33 \%, 51 \%$, to $79 \%$, respectively. Over the years, the job of spatial planner seems most popular, followed by environmental management. The most recent graduated geographers also take up jobs in research and consulting, cartography, GIS and remote sensing. Looking at the fields of employment not related to geography and outside education, an inverse development can be noted. This is to say that whereas in the past an important amount of geographers had to look for employment in banking and insurance, or in computing and telecommunications, this is no more (or less) the case nowadays.

In terms of the type of professional duty a lot of possibilities are noticeable (Table 11). Let us immediately mention the high proportion of geographers having a leading position (manager, director, and business manager) and - as expected - the increasing percentage of this type of position with age (young graduates (1994-2003) are not hired for a managing position as a start). A word of caution is however needed here, given that the respondents were left free in defining their answering categories.

Let us now consider the type of work contract for people being employed outside education. As expected, Table 12 shows that recently graduates have more temporary contracts. Let us also add that the percentage of self-employment has dropped in the last 20 years. This trend is also observable for jobs in education: teachers now have to wait for a longer time before they are permanently employed, and also civil servants are first given a temporary contract (training contract) prior to a permanent contract. 
Table 12. Contract terms outside education.

\begin{tabular}{lcccc}
\hline$\%$ & $<1974$ & $1974-1983$ & $1984-1993$ & $1994-2003$ \\
\hline Non permanent (definite) & 10 & 6 & 6 & 34 \\
Permanent (indefinite) & 73 & 74 & 85 & 59 \\
Trainee & 0 & 0 & 0 & 1 \\
Self-employment & 12 & 17 & 8 & 5 \\
Combination indefinite period & 0 & 1 & 0 & 0 \\
with being self-employed & 6 & 2 & 1 & 1 \\
Not known & 100 & 100 & 100 & 100 \\
\hline Total & & & &
\end{tabular}

By way of a summary, Figure 3 shows the relative distribution of the employment situation of geographers; it simply summarises what was formerly discussed in the paper.

Figure 3. Distribution of geographers in the labour market (\%).

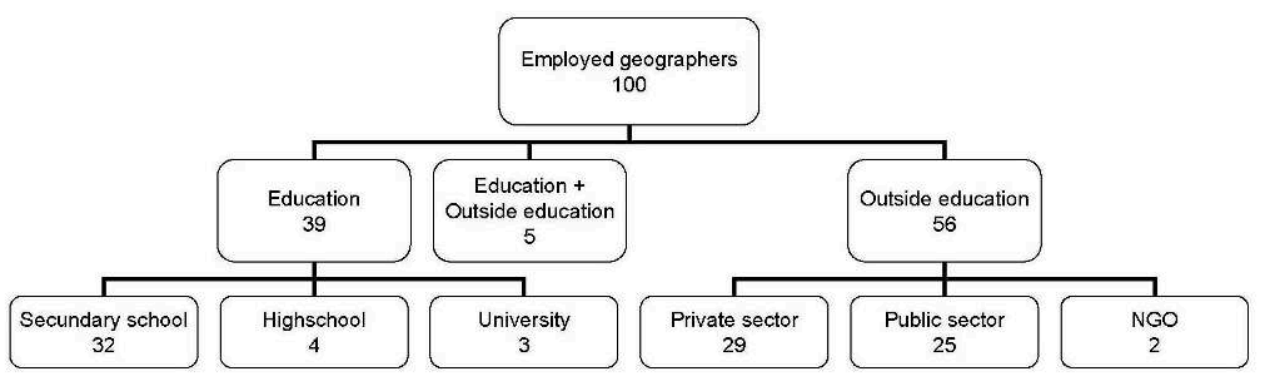

\section{Complementary studies}

Looking at Table 13 it can be noted that three quarters of all respondents obtained at least one complementary degree. A "complementary degree" means an additional diploma or certificate that was obtained besides a degree in geography. The percentage is the highest among the former generations (Table 14), and has dropped from $87 \%$ to $79 \%$ and $58 \%$ over the last twenty years. The latter percentage should to some extent be relegated since it does not take into account those graduated who are still studying for their additional degrees (18\%). The survey also indicates that relatively more women than men (63\% vs. 53\%) opt for an additional university degree. 
Table 13. Relationship between complementary degree and field of employment.

\begin{tabular}{|c|c|c|c|c|c|c|}
\hline$\%$ & education & $\begin{array}{l}\text { private } \\
\text { sector }\end{array}$ & $\begin{array}{l}\text { public } \\
\text { sector }\end{array}$ & others & unemployed & Total \\
\hline only geography & 6 & 36 & 33 & 21 & 43 & 24 \\
\hline $\begin{array}{l}\text { geography + teacher's } \\
\text { certificate }\end{array}$ & 71 & 21 & 19 & 33 & 34 & 40 \\
\hline geography + PhD & 1 & 0 & 2 & 3 & 0 & 1 \\
\hline geography + others & 2 & 21 & 25 & 15 & 8 & 14 \\
\hline $\begin{array}{l}\text { geography + teacher's } \\
\text { certificate + others }\end{array}$ & 14 & 17 & 17 & 19 & 10 & 16 \\
\hline $\begin{array}{l}\text { geography + PhD + others } \\
\text { geography + teacher's }\end{array}$ & 0 & 0 & 1 & 2 & 1 & 0 \\
\hline certificate $+\mathrm{PhD}$ & 3 & 2 & 1 & 4 & 4 & 3 \\
\hline $\begin{array}{l}\text { geography + teacher's } \\
\text { certificate + PhD + others }\end{array}$ & 2 & 1 & 2 & 2 & 1 & 2 \\
\hline Total & 100 & 100 & 100 & 100 & 100 & 100 \\
\hline
\end{tabular}

Table 14. Percentage of obtained complementary degree.

\begin{tabular}{lccccc}
\hline$\%$ & $<1974$ & $1974-1983$ & $1984-1993$ & $1994-2003$ & Total \\
\hline Yes & 85 & 87 & 79 & 58 & 75 \\
No & 15 & 13 & 21 & 42 & 25 \\
\hline Total & 100 & 100 & 100 & 100 & 100
\end{tabular}

Over the years, the number of complementary degrees obtained by one person has also decreased. Whereas in 1974 the average number of complementary degrees equals 1.30, in the 1994-2003 graduation period this is 0.94. The fact that there is a slight drop in the number of complementary diplomas is not that important. What is important however is the type of complementary study that is being undertaken. Here a significant drop can be noted among younger geography graduates to take up a teacher's certificate in favour for another university degree. In Table 15 the percentage of geography graduates obtaining a teacher's certificate drops from $88 \%$ in 1974 to $32 \%$ for the graduation period 1994-2003. Also important to note is the decline of the number of doctoral dissertations (PhD). However, for 1994-2003, the low figure of $3 \%$ might be explained in that people have not yet finished their PhD; hence are still working on it. 
Table 15. Different complementary degrees.

\begin{tabular}{lcccc}
\hline$\%$ & $<1974$ & $1974-1983$ & $1984-1993$ & $1994-2003$ \\
\hline Teacher's certificate & 88 & 79 & 65 & 32 \\
PhD & 15 & 6 & 6 & 3 \\
other & 27 & 28 & 42 & 41 \\
in progress & 1 & 3 & 4 & 18 \\
\hline Average number of diplomas & $1,30(1,30)^{*}$ & $1,16(1,14)^{\star}$ & $1,17(1,12)^{\star}$ & $0,94(0,75)^{*}$ \\
per geographer & \multicolumn{4}{c}{. } \\
\hline \multirow{2}{*}{$=$ average number diplomas per geographer without taking into account the studies in progress }
\end{tabular}

Given the increasing percentages of "other" complementary degrees - "other" in this case means no teacher's certificate or PhD - it is worthwhile to know what geography graduates are studying. This information is given in Table 16. Here again in view of interpreting this table a note of caution is necessary. This is because a global result is presented of a large variety of complementary studies that can be followed at the different universities, colleges, social promotion, day vs. evening education, etc.

Table 16. Other complementary degrees.

\begin{tabular}{lcccc}
\hline$\%$ & $<1974$ & $1974-1983$ & $1984-1993$ & 1994-2003 \\
\hline Applied sciences & 3 & 4 & 2 & 0 \\
Banking, insurance & 0 & 1 & 2 & 4 \\
Cartography, GIS, remote sensing & 10 & 5 & 6 & 6 \\
Computer science, telecommunication & 5 & 12 & 19 & 10 \\
Ecology, environmental management & 3 & 15 & 13 & 20 \\
Economics & 5 & 10 & 18 & 6 \\
Education, others than teacher's certificate & 10 & 3 & 2 & 2 \\
Exact and medical sciences & 12 & 6 & 2 & 18 \\
Human sciences & 22 & 11 & 10 & 1 \\
Mobility, transport & 0 & 1 & 2 & 7 \\
Others & 7 & 5 & 2 & 3 \\
PhD(training) in other sciences & 2 & 3 & 1 & 1 \\
Surveying, topography & 0 & 1 & 1 & 1 \\
Tourism & 2 & 5 & 2 & 3 \\
Spatial planning & 18 & 18 & 18 & 18 \\
Not known & 1 & 0 & 0 & 0 \\
\hline Total & 100 & 100 & 100 & 100
\end{tabular}

Table 16 has some obvious parallels with Table 10 (Employment activities). Again it comes as no surprise that spatial planning, and ecology and environmental management are high rated. Computer sciences, ICT and telecommunications also score rather well. New in the field are the complementary studies in the exact and medical sciences (e.g., mathematics, geology, nursery...).

\section{Conclusion}

This paper presents the results of a survey following the initiative of the Belgian National Committee of Geography in 2003. The survey focused on the present 
employment and complementary studies of Belgian geography alumni of six departments of geography in Belgium and that graduated between 1974 and 2003.

The main findings can be summarised as follows. With respect to employment, it is true to state that a geography degree still remains very much appreciated and valued in the labour market. The number of geography graduates out of work is exceptionally low (no or little unemployment). A shift in employment can however be noted. Whereas $53 \%$ of the geographers that graduated between 1974 and 1983 were employed in education (versus 37\% outside education), this percentage drops to 17\% for the 1994-2003 period (versus $66 \%$ outside education). Clearly, geography graduates are nowadays not exclusively predestined for a job as teacher, but more aspire to jobs outside education. This is to say that in a way the private sector as in 1974-1983 is now again "discovering" the geography graduate, albeit that the public sector is still the number one employer. Popular fields of employment remain spatial planning, and ecology and environmental management. However domains like research, consulting, cartography, GIS, remote sensing also come to the fore. It is fair to state that the results proposed here are not that surprising. The present survey confirms a number of the trends already mentioned in former studies (Beguin, 1997; Saey and Vandewalle, 1996; Kesteloot et al., 2000).

Closely linked to the changes in employment situations, is the change in obtaining a complementary degree: a large number of geography graduates pursue with an additional diploma. However, when twenty years ago this complementary study almost exclusively implied a teacher's certificate (in order to find a job in education), this is now changing to diplomas in spatial planning, environmental planning, computer sciences, and GIS (in order to find a job outside education). Maybe this fact can inspire us to speculate about the future impact of the new Bachelor-Master structure. This is to say: "Will the geography bachelor still choose to get his/her Master in Geography, or will he/she finish as a Bachelor in Geography, and obtain a Master in Spatial Planning, Environmental Sciences, Tourism, etc.?".

\section{BIBLIOGRAPHY}

BEGUIN H. (1983), “Les géographes et l'emploi”, Bulletin de la Société Belge d'Etudes Géographiques, 2, pp. 245-247.

BEGUIN H. (1988), “Le devenir des licenciés en géographie à l'UCL”, Bulletin de la Société Belge d'Etudes Géographiques, 2, pp. 377-384.

BEGUIN H. (1993), “Emploi et formation des licenciés en géographie de l'UCL”, Bulletin de la Société Belge d'Etudes Géographiques, 2, pp. 405-411.

BEGUIN H. (1997), “Les géographes de l'UCL: emploi et formation”, Bulletin de la Société Belge d'Etudes Géographiques, 2, pp. 262-269.

DEPUYDT F. (1988), “Een halve eeuw Leuvense geografen”, Tijdschrift van de Belgische Vereniging voor Aardrijkskunde Studies, 2, pp. 385-396. 
KESTELOOT C., THOMAS I., BEGUIN H., DE LANNOY W., DE DAPPER M., DE TURCK A., NICOLAÏ H. \& OZER A. (2000), "Belgian geographers at work: the occupation of graduates in 1999”, Belgeo, 1, pp. 241-249.

SAEY P. \& VANDEWALLE Y. (1996), "De werkgelegenheid van jonge geografen - Enquête 1994”, De Aardrijkskunde, 3, pp. 31-37.

Complementary websites about this survey:

For the main results pertaining to K.U.Leuven graduates

http://www.kuleuven.ac.be/geografie/schoolverlater/

For the main results pertaining to UCL graduates (2003 enquiry)

http://www.geog.ucl.ac.be

For the main results pertaining to ULB graduates (1999 enquiry)

http://www.ulb.ac.be/facs/sciences/geog/anciens.html

For the main results pertaining to VUB graduates (2003 enquiry)

http://www.vub.ac.be/DGGF/welcome.html

\section{ABSTRACTS}

This paper presents the results of the survey conducted under the auspices of the Belgian National Committee of Geography. The survey focused on the present employment and complementary studies of Belgian geography alumni of all Belgian universities that graduated before 2003. With respect to employment and to a large extent with respect to complementary studies and degrees, it is shown that the trend of obtaining a teacher's certificate is declining as well as of being employed in secondary and higher education. By contrast, spatial and regional planning, research and consulting, GIS, and ecology and environmental management have gained considerable interest as potential fields of employment outside education. The proportion of geography graduates being unemployed remains very low. This should keep the field quite attractive in the coming years.

L'article présente les résultats d'une enquête centrée sur la situation actuelle, en matière d'emploi et d'études complémentaires, des géographes diplômés des universités belges avant 2003. Cette étude, menée sous les auspices du Comité National Belge de Géographie, montre un recul de la filière agrégation ainsi que de l'emploi dans l'enseignement secondaire ou supérieur. En revanche, les domaines de l'aménagement spatial et régional, la recherche et consultance, les SIG, la gestion écologique et environnementale sont de plus en plus prisés en tant que source potentielle d'emploi hors enseignement. La proportion de géographes sans emploi demeure extrêmement faible, ce qui devrait garantir l'attrait de cette formaion dans les années à venir.

\section{INDEX}

Mots-clés: géographes belges, emploi des géographes, études complémentaires

Keywords: Belgian geographers, employment of geographers, complementary studies 


\section{AUTHORS}

\section{ISABELLE THOMAS}

Department of Geography, Université Catholique de Louvain, Louvain-la-Neuve, National Fund for Scientific Research, Brussels, isabelle@geog.ucl.ac.be

ANN VERHETSEL

Department of Transport and Regional Economics, University of Antwerp, Ann.Verhetsel@ua.ac.be

\section{FRANK WITLOX}

Department of Geography, Ghent University, Frank.Witlox@UGent.be 